\title{
Epstein-Barr virus in normal, pre-malignant, and malignant lesions of the uterine cervix
}

\author{
R J Landers, J J O'Leary, M Crowley, I Healy, P Annis, L Burke, D O'Brien, J Hogan, \\ W F Kealy, F A Lewis, C T Doyle
}

\begin{abstract}
Aim-To detect the presence or absence of Epstein-Barr virus (EBV) in cervical lesions ranging from normality to invasive malignancy.

Methods-Eighteen randomly selected cases of invasive squamous cell carcinomas of the uterine cervix were examined as well as 25 cases each of normal cervices and those showing cervical intraepithelial neoplasia (CIN) I, II, and III. DNA-DNA in situ hybridisation, using a biotinylated probe to the Bam H1 "W" fragment of $\mathrm{EBV}$, was carried out in addition to the polymerase chain reaction using specific primer sequences that flank a 153 base pair segment of the Bam $H 1$ "W" region of the EBV genome and which do not cross-amplify other DNA herpes viruses. Positive control material included paraffin wax embedded P3 HR1 lymphoblastoid cells (containing high copy numbers of EBV) and two nasopharyngeal carcinomas positive for EBV.
\end{abstract}

Results-Neither normal nor CIN I tissue was positive. Eight per cent of CIN II tissue was positive; $8 \%$ of CIN III, and $43 \%$ of carcinomas were positive for EBV.

Conclusion-The study shows that the virus is present in some cases of cervical carcinoma and to a lesser degree in some premalignant lesions of the cervix, but the exact association between it and cervical oncogenesis, be it causative or incidental, remains to be determined.

Department of Pathology, University College Cork, Cork, Ireland

R J Landers

J J O'Leary

M Crowley

I Healy

J Hogan

C T Doyle

Department of

Histopathology,

Regional Hospital,

Wilton, Cork

P Annis

L Burke

D O'Brien

W F Kealy

Department of

Pathology, University

of Leeds, Leeds

F A Lewis

Correspondence to:

Dr R J Landers

Accepted for publication 22 April 1993 (f Clin Pathol 1993;46:931-935)

Epstein-Barr virus (EBV) is a ubiquitous human herpes virus causing widespread and largely asymptomatic infection. Once infected, individuals become lifelong carriers. EBV efficiently immortalises B lymphocytes to perpetual growth. The virus is associated with three lymphoproliferative diseases of $B$ cell origin: (i) infectious mononucleosis; (ii) Burkitt's lymphoma; (iii) lymphomas in the immunocompromised.

This B cell tropism of EBV, however, is not consistent with the growing body of evidence linking EBV with epithelial cells. The association between EBV and undifferentiated nasopharyngeal carcinoma is well documented. ${ }^{2}$ Certain other carcinomas of, for example, tonsil, ${ }^{3}$ tongue, ${ }^{4}$ larynx, ${ }^{5}$ parotid, ${ }^{6}$ and thymus ${ }^{7}$ also show an association with
EBV. In these, however, the evidence is less conclusive and the consistency of the association has yet to be established.

Invasive carcinoma of the cervix is one of the commonest malignant tumours of the female genital tract. Much controversy surrounds its aetiology. The possibility of a sexually transmissible infectious carcinogen in the genesis of cervical neoplasia has received widespread attention. Possible agents include the herpes viruses, Chlamydia trachomatis, the human papillomaviruses (HPV), especially types 16 and 18 , and cytomegalovirus.

The association between EBV and the human uterine cervix is, as yet, not very well defined. Sixbey et al showed that cultured ectocervical epithelial cells can be infected with EBV. ${ }^{8}$ These authors also showed late viral antigens and EBV DNA in the exfoliating cells but not in the attached epithelial monolayer, thus suggesting an association between viral replication and epithelial differentiation. Infectious EBV capable of transforming B lymphocytes has been isolated from cervical washings from women recovering from infectious mononucleosis and from EBV seropositive women who had no clinical or serological evidence of acute EBV infection. ${ }^{9}$ This suggests that the cervix could be a site for chronic viral shedding in a manner similar to that which occurs in the nasopharynx. These studies show both in vitro and in vivo evidence for EBV replication in the cervix. In contrast to the nasopharynx, where there is a close association between epithelial and lymphoid tissues, no such association exists in the cervix, suggesting that cervical epithelium may be a primary site of EBV infection.

\section{Methods}

Eighteen cases of cervical squamous cell carcinoma as well as 25 cases each of normal cervices and those showing CIN I, II, and III were examined. All cases consisted of formalin fixed, routinely processed, and paraffin wax embedded surgical specimens retrieved from the archives, over a six year period (1985-1990). The only criterion used for block selection was that those blocks with the least amount of tissue necrosis were used to minimise possible problems with polymerase chain reaction (PCR) inhibitors. No attempt was made to select tumours according to the degree of differentiation, or to select cases from specific age groups. As positive control material, cells from a lymphoblastoid cell 


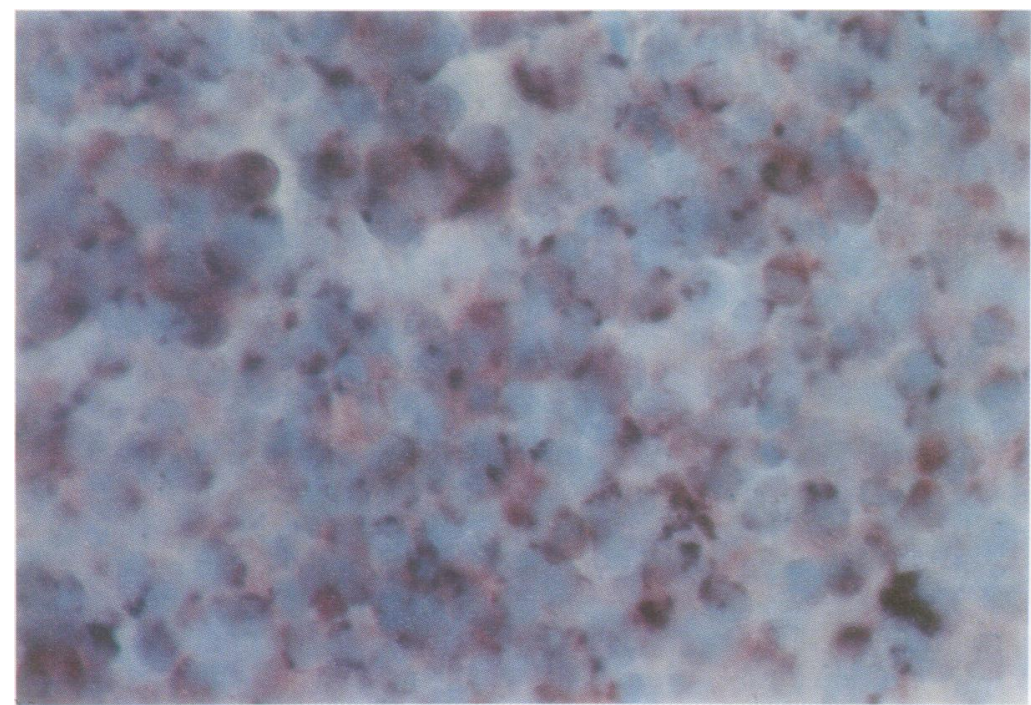

Figure 1 Formalin-fixed and paraffin-embedded P3HR1 lymphoblastoid cell line showing positive in situ hybridisation staining pattern for $E B V$.

P3HR1, which contains high copy numbers of EBV, were used in both studies (fig 1).

\section{PCR TECHNIQUE}

DNA was extracted from tissues by dewaxing and then boiling two $5 \mu \mathrm{m}$ sections at $100^{\circ} \mathrm{C}$ for 20 minutes. The resultant solution $(30 \mu \mathrm{l})$ was then taken for subsequent amplification. All reactions were carried out in sterile $0.5 \mathrm{ml}$ microcentrifuge tubes in a Perkin-Elmer Cetus DNA thermal cycler. The primers used flank a 153 base pair segment of the Bam H1 "W" region of the EBV genome and give no amplification when tested with cells infected with other human herpes viruses. Primer sequences (from published data) ${ }^{10}$ are as follows:

\section{Primer 1: CACTTTAGAGCTCTGGAGGA;} Primer 2: TAAAGATAGCAGCAGCGCAG.

These primers do not differentiate between EBV types A and B. Each PCR was carried out in total volumes of $100 \mu \mathrm{l}$ as follows: $10 \mu \mathrm{l}$ of $10 \times$ reaction buffer ( $10 \mathrm{mM}$ TRIS$\mathrm{HCl}, 50 \mathrm{mM} \mathrm{KCl}, 1.5 \mathrm{mM} \mathrm{MgCl}, 0.01 \%$ gelatin, $0.1 \%$ Triton $\mathrm{X} 100) ; 30 \mu \mathrm{l}$ of extracted DNA; $16 \mu \mathrm{l}$ of dNTP mix, $0.55 \mu \mathrm{l}$ of Taq polymerase (Promega); primers 1 and 2 (in concentrated ammonia with no volume correction required); and $43.45 \mu \mathrm{l}$ of high power liquid chromatography water. A total of 50 amplification cycles was carried out on each sample using the following cycling variables: denaturation at $94^{\circ} \mathrm{C}$ for 1 minute; primer annealing at $60^{\circ} \mathrm{C}$ for 30 seconds; and primer extension at $72^{\circ} \mathrm{C}$ for 1 minute. All reactions were covered by mineral oil to prevent evaporation.

Tissue sections from a paraffin wax embedded P3HR1 lymphoblastoid cell line, and from a case of nasopharyngeal carcinoma, were used as positive controls, and samples containing no template DNA were used as negative controls. The primers were also tested against fragments of whole CMV to ensure that no cross-amplification was tak- ing place. The amplified products were then visualised using $2 \%$ agarose gel electrophoresis, stained with ethidium bromide, and viewed under an ultraviolet transilluminator.

\section{IN SITU HYBRIDISATION}

Pre-treatment

All hybridisation reaction procedures were carried out in three stages using nick translated DNA probes. Pre-treatment steps included the placement of $5 \mu \mathrm{m}$ sections on APES coated single-well slides. Tissue sections were baked overnight at $60^{\circ} \mathrm{C}$ to acquire maximum section adherence. Sections were dewaxed in xylene for 30 minutes and were then hydrated through graded alcohols to distilled water over 30 minutes, and then immersed in phosphate buffered saline (PBS) for 5 minutes. The slides were immersed in $0.02 \mathrm{M}$ hydrochloric acid for 10 minutes, washed in PBS for 10 minutes, immersed in PBS containing $0.01 \%$ Triton X 100 for 90 seconds, and then washed in PBS for $10 \mathrm{~min}-$ utes. Slides were then incubated in a proteinase $\mathrm{K}$ solution $(50 \mathrm{mM}$ TRIS- $\mathrm{HCl}$ $(\mathrm{pH} 7 \cdot 6), 5 \mathrm{mM}$ EDTA, and proteinase $\mathrm{K}$ $(0.5 \mathrm{mg} / \mathrm{ml})$ at $37^{\circ} \mathrm{C}$ for 10 minutes. The slides were washed twice in PBS containing $2 \mathrm{mg} / \mathrm{ml}$ glycine and were immersed in $20 \%$ acetic acid in water for 15 seconds at $4^{\circ} \mathrm{C}$, washed through several changes of PBS, and post-fixed in $4 \%$ paraformaldehyde in PBS for 5 minutes. Sections were then washed in PBS for 5 minutes, dehydrated through graded ethanols, and stored in absolute ethanol before the hybridisation mixture was applied.

\section{DNA probes}

The DNA probes used were plasmid pBR322 (Gibco BRL) as a negative control probe, human placental DNA (Oncor) as a total DNA probe, and a $\mathrm{Bam} H 1$ "W" fragment of EBV contained in pBR322. The probes were biotinylated using biotin 11-dUTP (Sigma), using a nick translation kit (Gibco BRL) and following the recommended protocol. Unincorporated dNTPs were separated from the biotinylated DNA by the spun column technique on Sephadex G 50 (Pharmacia). The biotinylated probes were prepared at a concentration of $200 \mathrm{ng} / \mathrm{ml}$ in a hybridisation buffer containing $2 \times$ sodium nitrate and sodium sulphate (SSC), 5\% dextran sulphate, $0.2 \%$ dried milk powder (pure containing no vegetable extracts), and $50 \%$ formamide.

\section{Hybridisation}

Excess absolute alcohol was drained from the tissue sections. Hybridisation mixture $(75 \mu \mathrm{l})$ containing the probes were pipetted onto the prepared sections. The slide wells were covered with a piece of gel-bond (FMC Bioproducts), hydrophobic side down, and sealed with clear nail varnish. The slides were heated at $90^{\circ} \mathrm{C}$ for 10 minutes to denature cellular and probe DNA and were then transferred to an incubator at $42^{\circ} \mathrm{C}$ in a humidified box. The incubation was allowed to proceed over 18 hours at $42^{\circ} \mathrm{C}$. After this the 


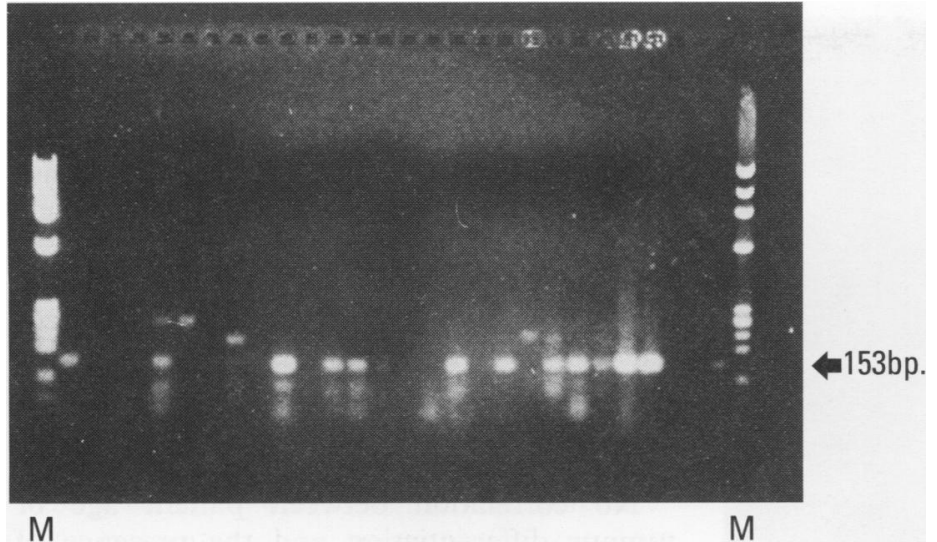

Figure 2 2\% Agarose gel electrophoresis of PCR products of cases and controls stained with ethidium bromide. $M=\varphi X 174$ Hae III digest.

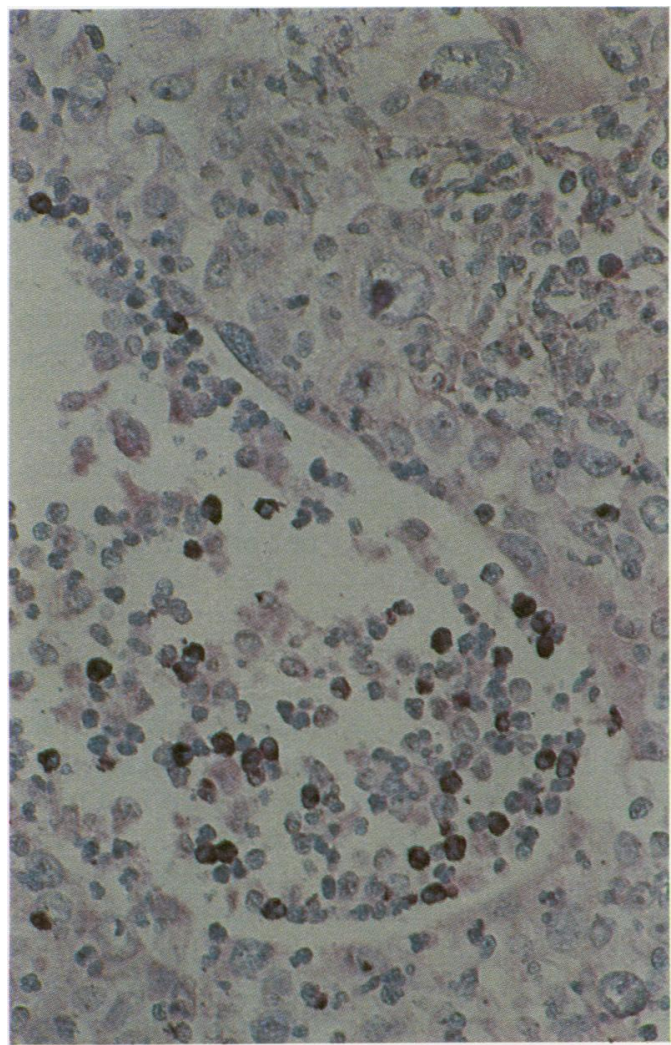

Figure 3 Invasive cervical squamous cell carcinoma showing positive in situ hybridisation signals for the presence of $E B V$.

gel-bond covering the wells was removed carefully and the slides immersed in $2 \times$ SSC for 10 minutes. Sequentially, the slides were washed in $2 \times \mathrm{SSC}$ at $60^{\circ} \mathrm{C}$ with agitation for 20 minutes, $0 \cdot 2 \times$ SSC for 10 minutes, $0.2 \times$ SSC at $42^{\circ} \mathrm{C}$ for 20 minutes, $0.1 \times$ SSC for 10 minutes, and finally $2 \times$ SSC for 2 minutes the hybridisation signal was detected.

\section{Detection of signal}

The slides were processed using a DNA detection kit (Dako) with some modifications to the recommended protocol. Briefly, the slides were immersed in buffer 2 (5\% bovine serum albumin in $0.1 \mathrm{M}$ TRIS- $\mathrm{HCl}(\mathrm{pH}$ 7.5), $0.1 \mathrm{M} \mathrm{NaCl}, 2 \mathrm{mM} \mathrm{MgCl}_{2}, 0.05 \%$
Triton X-100), to block non-specific streptavidin binding sites. The slides were drained of excess buffer and placed in a humidity chamber. An aliquot of streptavidin $(10 \mu \mathrm{l} / \mathrm{ml})$ in buffer $1(0.1 \mathrm{M}$ TRIS- $\mathrm{HCl}(\mathrm{pH} 7 \cdot 5), 0.1 \mathrm{M}$ $\mathrm{NaCl}, 2 \mathrm{mM} \mathrm{MgCl}_{2}, 0.05 \%$ Triton X-100) was added to each slide and incubated at room temperature for 10 minutes. The slides were washed for 5 minutes twice with agitation to remove excess buffer and were then returned to the humidified chamber. A solution of biotinylated polyalkaline phosphatase $(10 \mu \mathrm{l} / \mathrm{ml})$ in buffer 1 was applied to the slides and incubated for a further 10 minutes at room temperature. The slides were washed for 5 minutes twice in buffer 1 with agitation and immersed in buffer $3(0.1 \mathrm{M}$ TRIS-HCl (pH9.5), $0.1 \mathrm{M} \mathrm{NaCl}, 50 \mathrm{mM} \mathrm{MgCl}_{2}$ ) for 1 hour. The slides were returned to the humidified box and development reagent was applied. The development reagent, which was made fresh before use, was prepared by adding $44 \mu \mathrm{l}$ of nitroblue tetrazolium NBT (Gibco BRL) solution to $10 \mathrm{ml}$ of buffer 3 and gently mixed by inverting the tube. 5Bromo-4-chloro-3-indolyl phosphate (BCIP) (Gibco BRL) $(33 \mu \mathrm{l})$ was then added followed by gentle mixing. An appropriate volume, equal to about $2 \mathrm{ml}$ a slide was applied. The slides were incubated in subdued light for 30 minutes, and colour development was then monitored at 15 minute intervals during incubation until full development had been attained. After development the slides were immersed in PBS for $5 \mathrm{~min}$ utes, rinsed in three changes of PBS, and finally in water. Counterstaining was performed with $2 \%$ methyl green, then finally rinsed in distilled water and coverslip mounted with glycerine jelly. ${ }^{11}$

\section{Results}

Of those cases in which positive results were obtained, the in situ signals consisted predominantly of perinuclear staining with intranuclear and cytoplasmic staining visible in some malignant squamous epithelial cells.

All. cases positive by in situ hybridisation were confirmed by PCR except for three cases in the group with carcinoma. The results for the different groups are shown in the table (see also figs 2 and 3 ).

\begin{tabular}{ll} 
Results & \\
\hline Normal & PCR 0\% \\
& ISH 0\% \\
CIN I & PCR 0\% \\
& ISH 0\% \\
CIN II & PCR 8\% \\
& ISH 8\% \\
CIN III & PCR 8\% \\
& ISH 8\% \\
Carcinomas & PCR 43\% \\
& ISH 28\%
\end{tabular}

PCR = polymer chain-reaction

ISH $=$ in situ hybridisation 


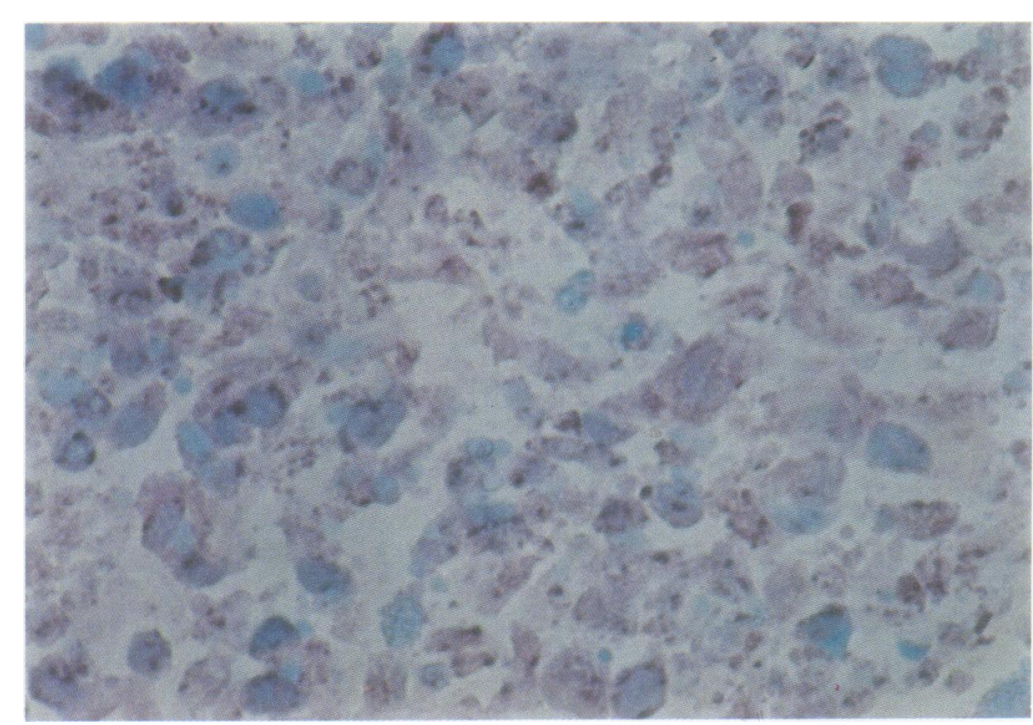

Figure 4 Peritumoural lymphocytes in a case of cervical carcinoma showing positive hybridisation signals for $E B V$. cervical cancer if they partner a man whose previous wife had cervical carcinoma. ${ }^{12}$ It is likely that EBV, in a manner similar to other herpes viruses and some types of HPV, can be transmitted sexually, although it is not known whether EBV can replicate in the male genital tract. The close association between EBV and nasopharyngeal carcinoma clearly indicates that the virus has oncogenic potential within an epithelial cell. Thus the virus may have a part to play in the aetiology or pathogenesis of cervical squamous cell carcinoma.

No correlation between patient age or tumour differentiation and the presence of virus was found.

The discrepancy in results between the two methods of virus detection has two possible explanations. First, DNA amplification using PCR is a more sensitive technique than the detection of viral DNA with in situ hybridisation using. non-radiolabelled probes, and theoretically even one particle of viral DNA in the tissue section should be detectable by PCR. It is possible that the three tumours negative in the in situ hybridisation study, but which gave positive results on PCR, may not have had adequate copy numbers of the virus to permit detection. Second, as has been shown, lymphocytes infiltrating the tumours on some tissue sections gave positive in situ hybridisation signals for the presence of virus and thus would give a positive result on PCR even though the tumour cells themselves may not contain any virus.

This last point emphasises the need for very careful interpretation of results obtained using PCR on tissue sections. Ideally PCR combined with in situ hybridisation is to be recommended as PCR results on their own merely indicate the presence of the virus in the tissues but not necessarily in the cell of interest.

The study, however, leaves many questions unanswered: what exactly is the role, if any, of EBV in the development of cervical carcinoma? How does the virus initially infect cervical tissues? Does the virus integrate into the host genome and promote malignant change? Is the virus, as we have detected, in an active or latent phase in these malignant cells? Such questions and others remain to be answered by future work directed towards establishing whether the virus can directly transform epithelial cells, and the precise mechanism(s) of EBV infection, either sexually haematogenously, or both.

In summary, ubiquitous though human infection with EBV is, this study shows a new association between the virus and cervical squamous cell carcinoma. The exact association, be it causative or incidental, remains to be determined.

1 Zur Hausen H, Schulte-Holthauzen H, Klein G, et al. EBV DNA in biopsies of Burkitt tumours and anaplastic carcinomas of the nasopharynx. Nature 1970;228: 1956-8.

2 Nonoyama M, Huang CH, Pagona JS, Klein G, Singh S. Burkitt's lymphoma and Proc Natl Acad Sci USA 1973;70:3265-8. with cervical carcinoma. ${ }^{12}$ This raises the possibility that human semen may activate latent EBV in vivo in the uterine cervix. Women have a three-fold increased risk of developing 
3 Brickacek B, Hirsch I, Sibl O, Vilikusova E, Vonka V. Presence of Epstein-Barr virus DNA in carcinomas of Presence of Epstein-Barr virus DNA in

4 Raab-Traub N, Flynn K, Klein C. EBV DNA structure and oncogene expression in EBV associated malignancies. In: Ablashi DV, Glaser R, Levine PH, Nonoyama $M$, Pearson GR, eds. Second international symposium on $E B V$ and associated malignant diseases. London: Humana Press, 1987:423-8.

5 Brickacek B, Hirsch I, Sibl O, Vilikusova E, Vonka V. Association of some supraglottic layrngeal carcinomas Association of some supraglottic layrngeal

6 Saemundsen AK, Albeck H, Hansen JPH, et al. EpsteinBarr virus in nasopharyngeal and salivary gland carcinomas in Greenland Eskimoes. Br $f$ Cancer 1982;46: mas in

7 Leyvraz S, Henle W, Chahinian AP, et al. Association of Epstein-Barr virus with thymic carcinoma. $N$ Engl $\mathcal{f}$ Med 1985;312:1296-9.

8 Sixbey JW, Vesterinen EH, Nedrud JG, Raab-Traub N,
Walton LA, Pagano JS. Replication of Epstein-Barr virus in human epithelial cells infected in vitro. Nature virus in human

9 Sixbey JW, Lemon SM, Pagano JS. A second site for Epstein-Barr virus shedding: the uterine cervix. Lancet 1986;ii:1122-4.

10 Coates PI, d'Ardenne AJ, Khan G, Kangro HO, Slavin G Simplified procedures for applying the polymerase chain reaction to routinely fixed paraffin wax sections. $f$ Clin Pathol 1991;44:115-8.

11 Zeng Y, Gi ZW, Ito Y. Epstein-Barr virus activation by human semen principle: Synergistic effects of culture fluids of bacteria isolated from patients with carcinoma

12 Lewis FA, Griffiths S, Ducliffe R, Wells M, Dudding N, Bird C. Sensitive in situ hybridisation technique using biotin-streptavidin-polyalkaline phosphatase complex. f Clin Pathol 1987;40:163-6.

13 Kessler II. Etiological concepts in cervical carcinogenesis. Gynecol Oncol 1981;12:S7-24. 